\title{
A NEW CASCADE SOLAR DESALINATION SYSTEM WITH INTEGRATED THERMOSYPHONS
}

\author{
Mukhsinun Hadi Kusuma ${ }^{1,2^{*}}$, Nandy Putra ${ }^{1}$, Rizky Esa Respati ${ }^{1}$ \\ ${ }^{1}$ Heat Transfer Laboratory, Department of Mechanical Engineering, Faculty of Engineering, \\ Universitas Indonesia, Kampus UI Depok, Depok 16424, Indonesia \\ ${ }^{2}$ Centre for Nuclear Reactor Safety and Technology, National Nuclear Energy Agency of Indonesia \\ (BATAN), Kawasan Puspiptek Serpong, Tangerang Selatan, 15314, Indonesia
}

(Received: December 2017 / Revised: December 2017 / Accepted: February 2018)

\begin{abstract}
Current cascade solar desalination systems can convert sea water into fresh water, but they can only produce small quantities. To produce more fresh water, there is a solution that can be applied, i.e. modification of the existing desalination system by adding thermosyphons. The objective of this research is to design a cascade solar desalination system with integrated thermosyphons and to establish its ability to produce fresh water. The experimental study was conducted by adding an aluminum absorber plate as a heat absorber in the upper tub, and nine copper thermosyphons with each length of $60 \mathrm{~cm}$ in the bottom of the tub. Thermosyphons with an inclination angle of $15^{\circ}$ were used as a solar energy absorber and heat enhancer for sea water. The experiment was performed with varying sea water flow rates of 3600, 7200, and $10800 \mathrm{~mL} / \mathrm{h}$, and levels of sea water in the upper tub of 2, 3, and $4 \mathrm{~cm}$. To compare the amount of fresh water obtained from the utilization of the thermosyphons, we also used the cascade solar desalination system without the thermosyphons. The results show that the cascade solar desalination system with integrated thermosyphons was able to produce an average amount of fresh water of $38.6 \mathrm{~mL} / \mathrm{h}$, with an average daily thermal efficiency of $18.78 \%$. On the other hand, the same system without the thermosyphons produced on average $9.9 \mathrm{~mL} / \mathrm{h}$ of fresh water, with an average daily thermal efficiency of $8 \%$. The results indicate that the use of thermosyphons in the cascade solar desalination system can increase fresh water productivity by up to 3.89 times, and increase the thermal efficiency of the system by up to 2.35 times.
\end{abstract}

Keywords: Cascade solar desalination; Heat pipe; Solar energy; Thermosyphon

\section{INTRODUCTION}

Water is an essential need for human life. It can be consumed as drinking water, produces electricity by hydroelectricity, and has many industrial uses. About $97 \%$ of water is in the oceans in the form of sea water, with the remaining $3 \%$ available as fresh water. With population and industrial growth, increasing fresh water needs are becoming significant. It must be realized that we cannot continue to rely only on groundwater sources; sea water needs to be utilized as another source of fresh water (Manju \& Sagar, 2017; Morad et al., 2017). Indonesia, as a maritime country, has many sources of sea water that can be utilized for fresh water.

However, sea water cannot be directly used as a source of fresh water. Desalination is a method to convert saline water into fresh water, using, for example, solar energy (Li et al., 2018; Lior \& Kim, 2018), microbial desalination cell technology (Utami et al., 2015; Zuhri et al., 2016),

*Corresponding author's email: Iuluikal@batan.go.id, Tel. +62-85883138229, Fax. +62-21-7560913

Permalink/DOI: https://dx.doi.org/10.14716/ijtech.v9i2.990 
and electrical energy (Haribowo et al., 2017). Solar desalination is suitable for development in an archipelago such as Indonesia, with minimal electricity distribution. One solar desalination method is thermal desalination, which is combined with heat pipe technology (also called a thermosyphon, since no wick is used inside the heat pipe) (Jouhara et al., 2009; Abad et al., 2013).

The heat pipe, as a passive system technology, can be utilized to assist the desalination process because it displays good thermal performance in removing heat from the heat source to the heat sink. There has been much research on heat pipes as heat absorbers and conductors. Heat pipes have good thermal performance in removing heat generation in electronic devices (Putra et al., 2014), in electric vehicle applications (Putra et al., 2016), in nuclear spent fuel pools (Kusuma et al., 2017; Kusuma et al., 2018), in refrigeration cycles (He et al., 2017), in space applications (Ando et al., 2018), in the ventilation of residential buildings (Diao et al., 2017), and in surgery rooms in hospitals (Noie-Baghban \& Majideian, 2000).

Many researchers have studied heat pipes as passive cooling devices integrated with desalination tubs to enhance the productivity of fresh water in the desalination process. The use of heat pipes in glass tub thermal desalination can produce a clean water output of up to $3.61 \mathrm{~kg} / \mathrm{day}$ (Rajaseenivasan et al., 2016), while a multilevel desalination tub with an evacuated vacuum tube can produce up to $855 \mathrm{ml} /\left(\mathrm{m}^{2} . \mathrm{h}\right.$ ) of fresh water (Panchal \& Shah, 2013); a pulsating heat pipe integrated with a desalination tub with an active heating method has a clean water output of up to $875 \mathrm{ml} /\left(\mathrm{m}^{2} . \mathrm{h}\right.$ ) (Abad et al., 2013); a desalination process using a wickless heat pipe vacuum tube can produce up to $1,02 \mathrm{~kg} /\left(\mathrm{m}^{2} . \mathrm{h}\right.$ ) (Mamouri et al., 2014); a solar distillation still with a vacuum tube and heat pipes can produce up to $40 \mathrm{~kg} /$ day of fresh water (Huang et al., 2015); and desalination apparatus combined with heat pipes and a parabolic collector $0.933 \mathrm{~kg} /\left(\mathrm{m}^{2} \cdot \mathrm{h}\right)$ (Mosleh et al., 2015).

No previous studies have researched the desalination process using dynamic seawater flow integrated with a plate absorber and thermosyphons. The objective of this research is to design a cascade solar desalination system with integrated thermosyphons and to establish its ability to produce fresh water. The experimental study was conducted by adding an aluminum absorber plate as a heat absorber in the upper tub, and nine copper thermosyphons with each length of 60 $\mathrm{cm}$ in the bottom of the tub. Thermosyphons with an inclination angle of $15^{\circ}$ were used as a solar energy absorber and additional heat for the sea water. The experiment was conducted with varying inlet flow rates and levels of sea water in the upper desalination tub. To compare the productivity of fresh water that was obtained from the cascade solar desalination system with integrated thermosyphons, we also conducted the experiment using a cascade solar desalination system without thermosyphons.

\section{METHODS}

\subsection{Experimental Setup}

The experimental setup and test section of the cascade solar desalination system with integrated thermosyphons can be seen in Figures 1 and 2.

From Figure 1, we can see that the cascade solar desalination system with integrated thermosyphons consists of nine thermosyphons, desalination tub, reservoir tank, aquarium pump, flow meter, circulation tank, container, beaker glass, and data acquisition system.

Nine thermosyphons were used in this investigation, each thermosyphon was made of copper pipe with a diameter of $0.95 \mathrm{~cm}$ and length of $60 \mathrm{~cm}$. Copper was used as the thermosyphon material since it has high thermal conductivity $(\mathrm{K}=400 \mathrm{~W} / \mathrm{m}$. K). Thermosyphons were used as solar heat absorbers for the solar desalination system. Each thermosyphon was divided into two sections: the evaporator and condenser. Each evaporator and condenser has an equal aspect ratio 
of $30 \mathrm{~cm}$. The evaporator was placed outside the tub and the condenser into a lower tub of the solar desalination system. Before they were applied to the solar desalination system, the thermosyphons were evacuated in order to remove their non-condensable gas. The demineralized water as the working fluid was then charged into the thermosyphons with a filling ratio of $60 \%$.

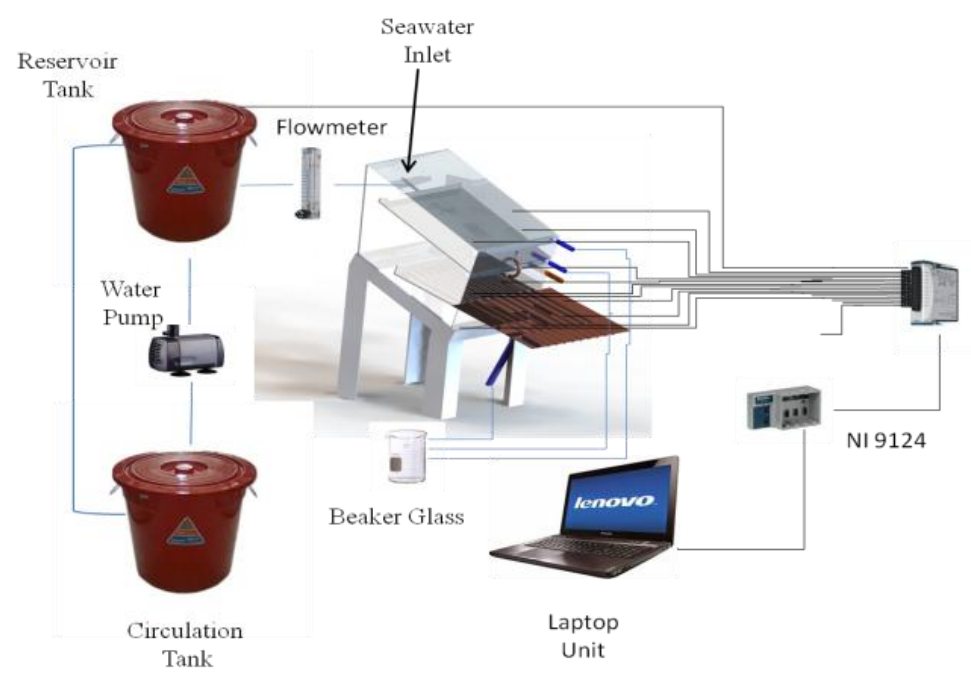

Figure 1 Experimental setup of cascade solar desalination system with integrated thermosyphons

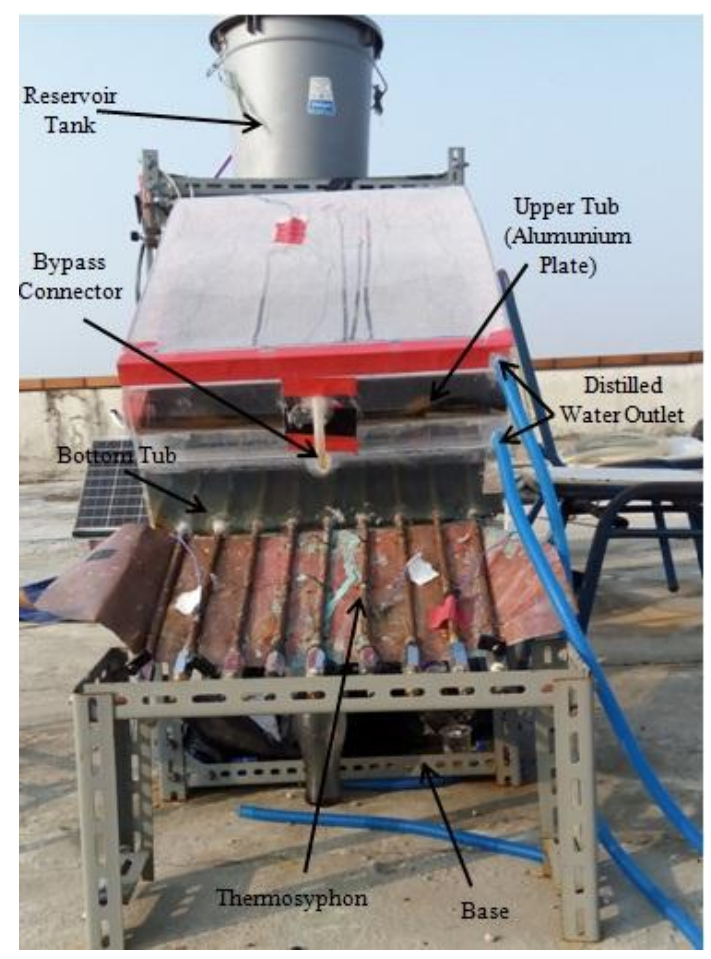

Figure 2 Test section of the cascade solar desalination system with integrated thermosyphons

The desalination tub was made of an acrylic material with dimensions of $50 \mathrm{~cm} \times 50 \mathrm{~cm} \times 40$ $\mathrm{cm}$. Aluminimum was placed inside the tub to increase the heat absorbed and a carpet was installed to flatten the fluid movement inside the tube. In the desalination tub, there were inlet tracks, outlet tracks, absorber-1, absorber-2, bypass-1, bypass-2, and thermosyphons. The desalination tub had an inclination angle of $28^{\circ}$ for the upper desalination tub, and $15^{\circ}$ for the bottom tub. The tub had one input line for sea water and three output lines for water condensation. 
The working process of the cascade solar desalination system is as follows. The sea water in the circulation tank is pumped into the reservoir tank. Once there, the water flows naturally into the desalination tub. The flow rate of the sea water is adjusted using a manual flow meter to maintain the sea water flow rate and its level in the desalination tub. The sea water in the upper desalination tub is exposed by solar power. Some of the sea water is evaporated and later a condensation process occurs in the condenser section of the thermosyphon. The remaining non-condensable sea water in the upper tub flows towards the bottom of the desalination tub through bypass line 1 and receives the heat released by the thermosyphon condenser. As a result of the heat released by the thermosyphon, the sea water in the desalination tub evaporates in the second stage until the condensation process takes place. Some of non-evaporated sea water in the second stage will become warm water. The result of condensation fluid (desalinated water) in the desalination tub is fresh water, which flows through the outlet line to the reservoir.

To determine the effect of sea water flow rate on fresh water production by cascade solar desalination, varying rates of 3600,7200 , and $10800 \mathrm{ml} / \mathrm{h}$ were employed. The volume of sea water in the basin was varied to determine the ability of the thermosyphons to take the heat in order to increase the volume of sea water, and to establish the effect of the thermosyphon condenser immersed in the basin on the production of fresh water (thermosyphons were installed in the basin at an inclination angle of $15^{\circ}$ ). The water level in the desalination tub varied between 2,3 and $4 \mathrm{~cm}$.

The experimental temperature data were recorded using the temperature module of a National Instrument data acquisition system. Fifteen channels of K type thermocouples were placed on the test section: one thermocouple on the reservoir tank, one on bypass line 1, two on the thermosyphon evaporator, two on the thermosyphon condenser, one on the upper absorber plate, one on the bottom absorber plate, one on the inner plastic film, one on the bottom of the plate, one on the bottom of the outer plastic film, one on the bottom of the bottom absorber plate, one on the bottom of the desalination tub, and one thermocouple was used to measure the ambient temperature.

\subsection{Thermal Efficiency of Cascade Solar Desalination}

The thermal efficiency of the cascade solar desalination system can be expressed as (Mosleh et al., 2015):

$$
\eta=\frac{\dot{m} h_{f g}}{I A}
$$

where $\eta$ is efficiency, $\dot{\mathrm{m}}$ is the mass flow rate of fresh water $(\mathrm{kg} / \mathrm{s}), h_{f g}$ is the latent heat of water vapor $(\mathrm{J} / \mathrm{kg}), I$ is the intensity of total solar radiation on the collector plate area, and $A$ is the collector plate area $\left(\mathrm{m}^{2}\right)$.

\section{RESULTS AND DISCUSSION}

The results were obtained from a cascade solar desalination system with and without integrated thermosyphons. The amounts of fresh water that resulted from varying mass flow rates and levels of sea water in the desalination tub are displayed in Figure 3.

It can be seen from Figure 3 that the average amounts of fresh water produced from the cascade solar desalination system with integrated thermosyphons at mass flow rates of 3600, 7200 and $10800 \mathrm{ml} / \mathrm{h}$ for levels of sea water in the desalination tub of 2,3 and $4 \mathrm{~cm}$ were $38.25,38.55$ and $39.07 \mathrm{ml} / \mathrm{h}$, respectively. 


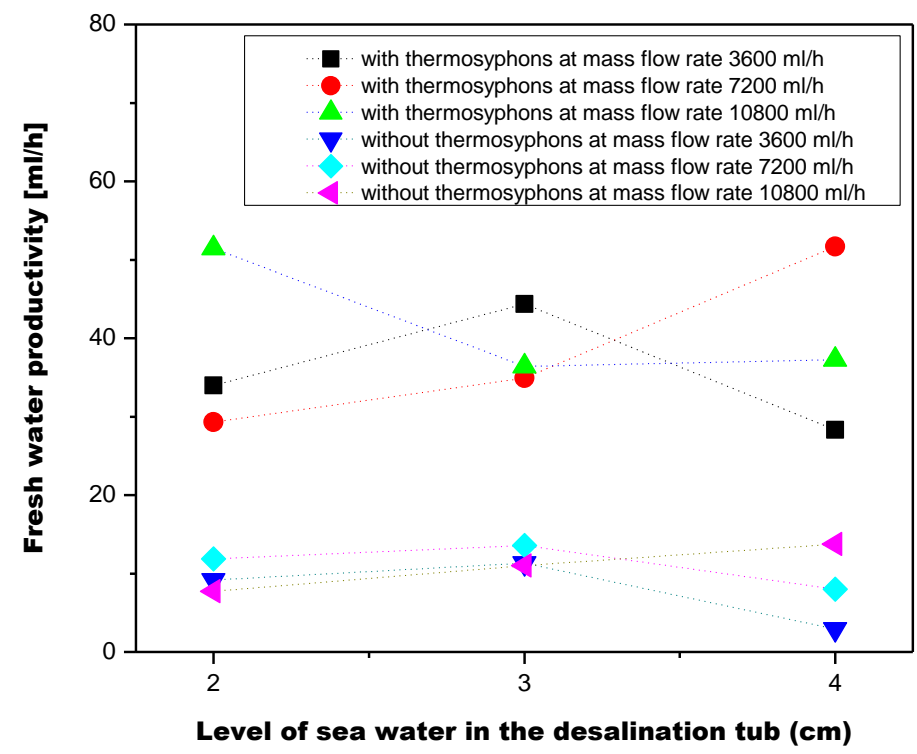

Figure 3 Fresh water productivity at varying mass flow rates and levels of sea water in the desalination tub

On the other hand, the average amounts from the system without thermosyphons were 9.59, 11.96 and $8.24 \mathrm{ml} / \mathrm{h}$, respectively. Based on the experimental results above, the addition of thermosyphons in the cascade solar desalination system produced more fresh water than in the system without thermosyphons. The plate used in the system was very effective as a solar heat absorber; the heat was then absorbed by the thermosyphons evaporator and was thus transported to the cascade solar desalination system. There were at least two ways of heat transport from the solar power to the system; by heat conduction through the whole of the outer surface of the thermosyphons, and by the thermosyphons operation in two phases due to the heat absorbed by the evaporator.

The discussion of the results is only based on those related to the working of the thermosyphons in the cascade solar desalination system, not on the heat which was transferred into the system by conduction. The heat absorbed by the evaporator section caused the working fluid in the thermosyphons to boil and later evaporate. The boiling of the working fluid occurred at low temperatures because the thermosyphons had been vacuumed. The steam generated in the evaporator section then rose to the condenser section that was submerged in the desalination tub. The latent heat of the vapor was then absorbed by the sea water, resulting in additional heat for the evaporation of the water. The vapor in the condenser section turned into condensate because the heat was absorbed by the sea water. Since the condensate density is heavier than the density of the vapor, the condensate dropped by gravity to the evaporator, so a natural circulation process occurred continuously in the thermosyphons. The heat, which was accumulated in the desalination tub, resulted in faster evaporation of sea water, and subsequently resulted in higher fresh water production compared to the cascade solar desalination system without thermosyphons. From Figure 3, no effects of the increase in mass flow rates and levels of sea water on fresh water productivity can be seen. This is because the solar intensity received by the cascade solar desalination system, with or without an integrated thermosyphons, had different values, although the experiments were conducted at similar times each day.

The solar intensity values which were received by the cascade solar desalination system with variation of mass flow rate and level of sea water in the desalination tub, integrated with a thermosyphons or without one, can be seen in Figures 4 and 5. 


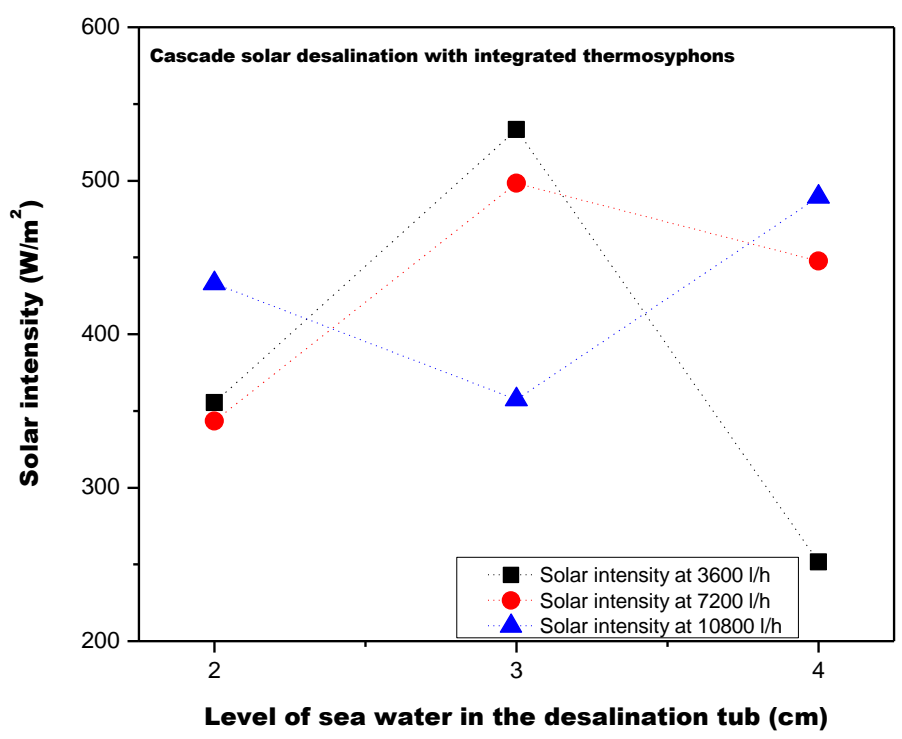

Figure 4 Solar intensity received by the cascade solar desalination system with integrated thermosyphons

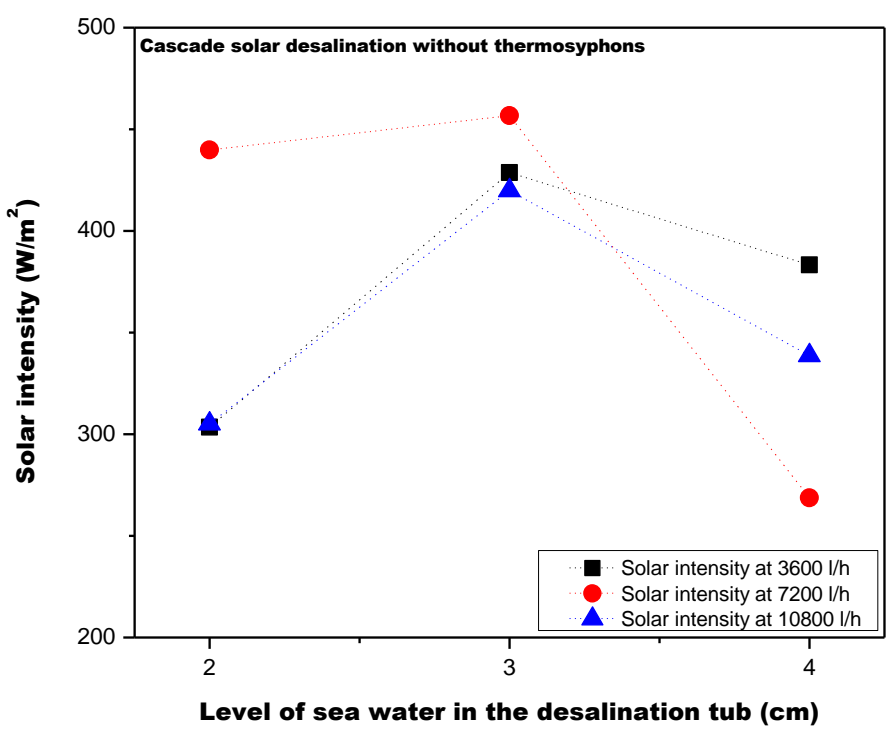

Figure 5 Solar intensity received by the cascade solar desalination system without thermosyphons

From Figures 4 and 5, it can be seen that the solar intensity received by the systems with and without integrated thermosyphons did not have the same, or nearly the same, values in all the experiments performed. As a result, fresh water and daily thermal efficiency that were produced were different, as seen in Figure 6. However, it was certain that the use of thermosyphons in the cascade solar desalination system resulted in more fresh water production than from the system without thermosyphons.

Figure 6 shows the daily thermal efficiencies which were obtained from the cascade solar desalination systems with and without integrated thermosyphons.

It can be seen from Figure 6 that the average daily thermal efficiencies in the desalination solar cascade systems with and without an integrated thermosyphons were highly dependent on solar intensity values. The average daily thermal efficiencies of the system with thermosyphons were higher than those of the system without one. 


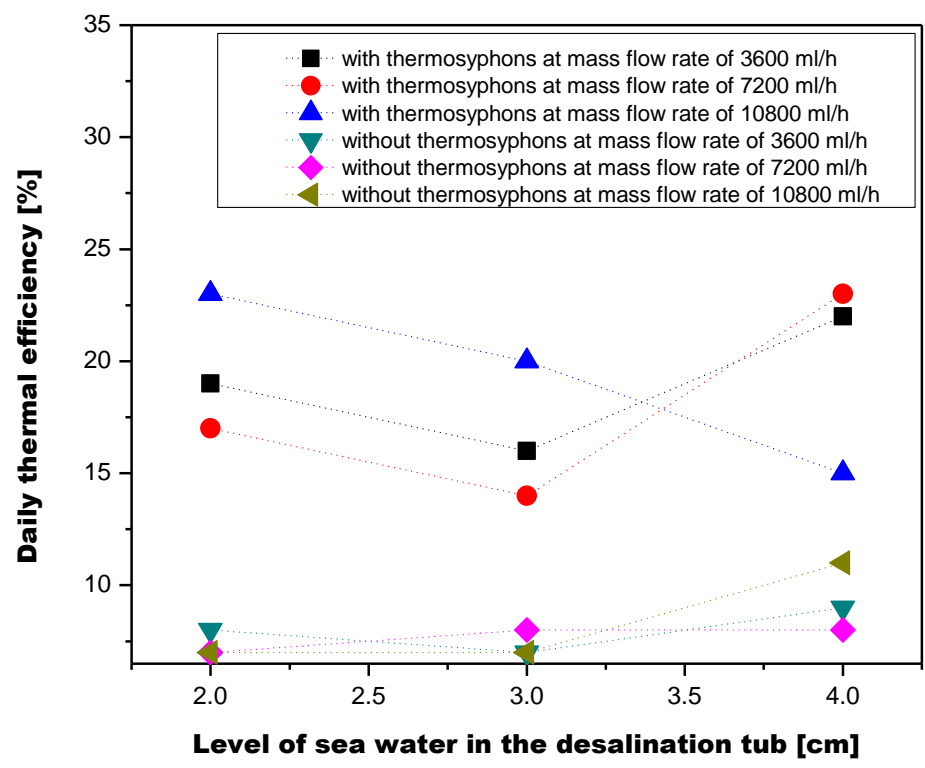

Figure 6 Daily thermal efficiencies at varying mass flow rates and levels of sea water in the desalination tub

The results show that the average daily thermal efficiencies of the former, at mass flow rates of 3600,7200 and $10800 \mathrm{ml} / \mathrm{h}$ for levels of sea water in the desalination tub of 2,3 and $4 \mathrm{~cm}$, were 19.67, 16.67, and 20\%, respectively. On the other hand, the corresponding efficiencies of the system without thermosyphons at mass flow rates of 3600, 7200 and $10800 \mathrm{ml} / \mathrm{h}$ for levels of sea water in the desalination tub of 2,3 and $4 \mathrm{~cm}$, were $7.33,7.33$ and $9.33 \%$, respectively.

More details of the effect of solar intensity on fresh water production and thermal efficiency in the cascade solar desalination systems can be seen in Figures 7 and 8, which show the experimental results obtained from the two systems at levels of sea water of $2 \mathrm{~cm}$ and varying mass flow rates.

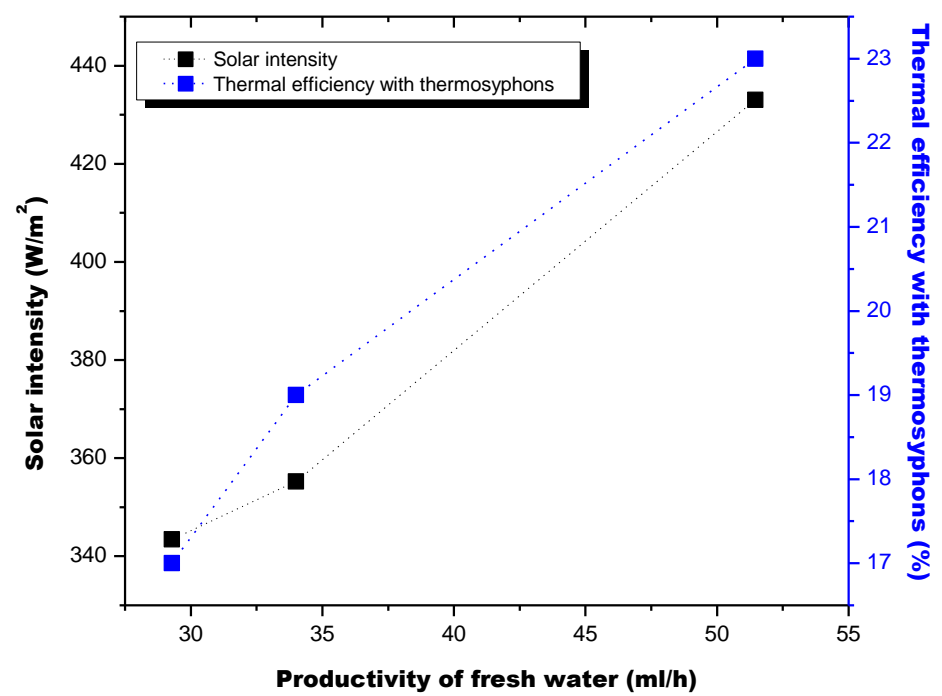

Figure 7 Effect of solar intensity on productivity of fresh water and thermal efficiency in cascade solar desalination system with integrated thermosyphons 


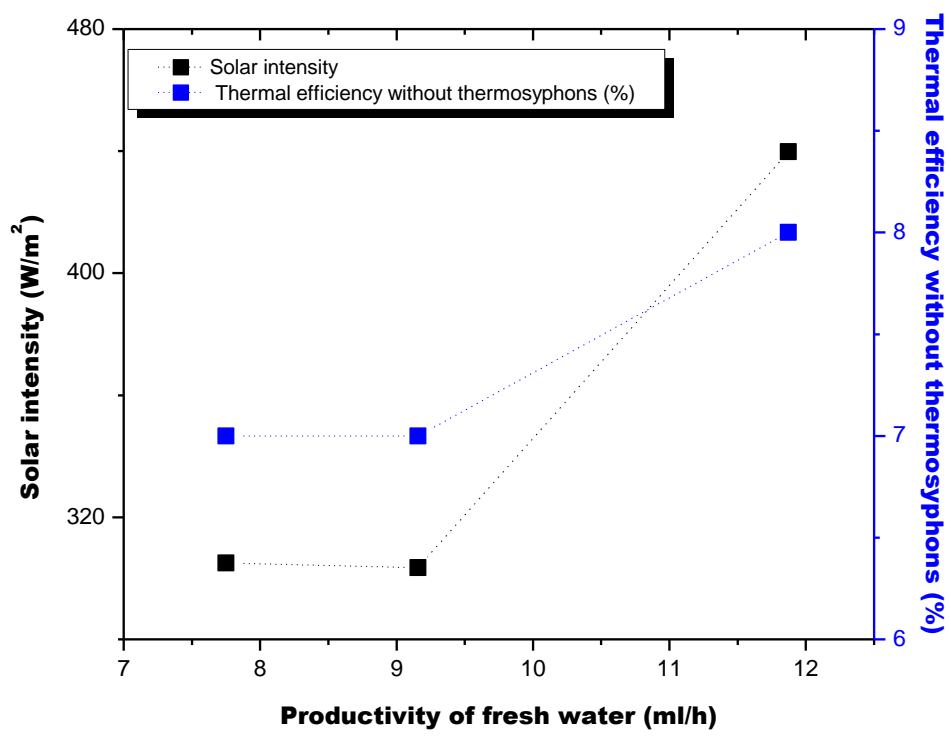

Figure 8 Effect of solar intensity on productivity of fresh water and thermal efficiency in cascade solar desalination without thermosyphons

Figures 7 and 8 show that solar intensity had a very significant influence on the fresh water production and thermal efficiency produced by the two systems. On the other hand, the experimental results show that the thermosyphons were very effective in increasing fresh water productivity. The addition of the thermosyphons was very effective in increasing the amount of heat required by sea water to be condensed into fresh water. The heat which was released by the condenser section increased the heat accumulation in the desalination tub, thus the amount of condensate which was produced by the desalination tub also increased.

\section{CONCLUSION}

An experimental investigation into a cascade solar desalination system with and without integrated thermosyphons has been conducted. The average fresh water productivity of the system with thermosyphons with varying mass flow rates and levels of sea water was $38.62 \mathrm{ml} / \mathrm{h}$, with an average daily thermal efficiency of $18.78 \%$. On the other hand, the average fresh water productivity of the system without thermosyphons was $9.93 \mathrm{ml} / \mathrm{h}$, with an average daily thermal efficiency of $8 \%$. The comparison results which were obtained show that the system with integrated thermosyphons was able to increase the solar heat transfer to the desalination system, increased fresh water productivity by up to 3.89 times, and increased thermal efficiency by up to 2.35 times. The addition of the thermosyphons as a passive cooling device had a significant effect in increasing the evaporation of sea water in the system; therefore, it increased the amount of heat required by sea water to condense into fresh water.

\section{ACKNOWLEDGEMENT}

The authors would like to thank the DRPM Universitas Indonesia for funding this research through the "PITTA 2017" scheme No. 816/UN2.R3.1/HKP.05.00/2017.

\section{REFERENCES}

Abad, H.K.S., Ghiasi, M., Mamouri, S.J., Shafii, M.B., 2013. A Novel Integrated Solar Desalination System with a Pulsating Heat Pipe. Desalination, Volume 311, pp. 206-210 
Ando, M., Okamoto, A., Tanaka, K., Maeda, M., Sugita, H., Daimaru, T., Nagai, H., 2018. Onorbit Demonstration of Oscillating Heat Pipe with Check Valves for Space Application. Applied Thermal Engineering, Volume 130, pp. 552-560

Diao, Y.H., Liang, L., Kang, Y.M., Zhao, Y.H., Wang, Z.Y., Zhu, T.T., 2017. Experimental Study on the Heat Recovery Characteristic of a Heat Exchanger based on a Flat Micro-heat Pipe Array for the Ventilation of Residential Buildings. Energy and Buildings. Volume 152, pp. 448-457

Haribowo, R., Yuliani, E., Prasetyo, A.G., 2017. Development of Seawater Distiller that Uses Electrical Energy for Sustainable Clean Water Production. International Journal of Technology. Volume 8(3), pp. 477-485

He, T., Mei, C., Longtin, J.P., 2017. Thermosyphon-assisted Cooling System for Refrigeration Applications. International Journal of Refrigeration. Volume 74, pp. 165-176

Huang, B.-J., Chong, T.-L., Wu, P.-H., Dai, H.-Y., Kao, Y.-C., 2015. Spiral Multiple-effect Diffusion Solar Still Coupled with Vacuum-tube Collector and Heat Pipe. Desalination, Volume 362, pp. 74-83

Jouhara, H., Anastasov, V., Khamis, I., 2009. Potential of Heat Pipe Technology in Nuclear Seawater Desalination. Desalination, Volume 249, pp. 1055-1061

Kusuma, M.H., Putra, N., Antariksawan, A.R., Koestoer, R.A., Widodo, S., Ismarwanti, S., Verlambang, B.T., 2018. Passive Cooling System in a Nuclear Spent Fuel Pool using a Vertical Straight Wickless-heat Pipe. International Journal of Thermal Sciences. Volume 126, pp. 162-171

Kusuma, M.H., Putra, N., Ismarwanti, S., Widodo, S., 2017. Simulation of Wickless-heat Pipe as Passive Cooling System in Nuclear Spent Fuel Pool using RELAP5/MOD3.2. International Journal on Advanced Science, Engineering and Information Technology. Volume 7(3), pp. 836-842

Li, Z., Siddiqi, A., Anadon, L.D., Narayanamurti, V., 2018. Towards Sustainability in Waterenergy Nexus: Ocean Energy for Seawater Desalination. Renewable and Sustainable Energy Reviews. Volume 82, pp. 3833-3847

Lior, N., Kim, D., 2018. Quantitative Sustainability Analysis of Water Desalination - A Didactic Example for Reverse Osmosis. Desalination. Volume 431, pp. 157-170

Mamouri S.J., Derami H.G., Ghiasi M., Shafii M.B., Shiee Z., 2014. Experimental investigation of the effect of using thermosyphon heat pipes and vacuum glass on the performance of solar still. Energy, Volume 75, pp. 501-7

Manju, S., Sagar, N., 2017. Renewable Energy Integrated Desalination: A Sustainable Solution to Overcome Future Fresh-water Scarcity in India. Renewable and Sustainable Energy Reviews, Volume 73, pp. 594-609

Morad, M.M., El-Maghawry, H.A.M., Wasfy, K.I., 2017. A Developed Solar-powered Desalination System for Enhancing Fresh Water Productivity. Solar Energy, Volume 146, pp. 20-29

Mosleh, H.J., Mamouri, S.J., Shafii, M.B., Sima, A.H., 2015. A New Desalination System using a Combination of Heat Pipe, Evacuated Tube and Parabolic through Collector. Energy Conversion and Management, Volume 99, pp. 141-150

Noie-Baghban, S.H., Majideian, G.R., 2000. Waste Heat Recovery using Heat Pipe Heat Exchanger (HPHE) for Surgery Rooms in Hospitals. Applied Thermal Engineering, Volume 20(14), pp. 1271-1282

Panchal H.N., Shah P.K., 2013. Performance analysis of double basin solar still with evacuated tubes. Appl Sol Energy, Volume 49(3), pp. 174-9

Putra, N., Ariantara, B., Pamungkas, R.A., 2016. Experimental Investigation on Performance of Lithium-ion Battery Thermal Management System using Flat Plate Loop Heat Pipe for Electric Vehicle Application. Appl. Therm. Eng, Volume 99, pp. 784-789 
Putra, N., Saleh, R., Septiadi, W.N., Okta, A., Hamid, Z., 2014. Thermal Performance of Biomaterial Wick Loop Heat Pipes with Water-base $\mathrm{Al}_{2} \mathrm{O}_{3}$ Nanofluids. International Journal of Thermal Sciences, Volume 76, pp. 128-136

Rajaseenivasan T, Tinnokesh AP, Kumar GR, Srithar K, 2016. Glass basin solar still with integrated preheated water supply-theoretical and experimental investigation. Desalination, Volume 398, pp. 214-21

Utami, T.S., Arbianti, R., Manaf, B.N., 2015. Sea Water Desalination using Debaryomyces hansenii with Microbial Desalination Cell Technology. International Journal of Technology. Volume 6(7), pp. 1094-1100

Zuhri, F., Arbianti, R., Utami, T.S., Hermansyah, H., 2016. Effect of Methylene Blue Addition as a Redox Mediator on Performance of Microbial Desalination Cell by Utilizing Tempe Wastewater. International Journal of Technology. Volume 7(6), pp. 952-961 